\title{
Land use effects and stream metabolic rates: a review of ecosystem response
}

\author{
Efeitos do uso do solo nas taxas metabólicas de córregos: \\ uma revisão das respostas ecossistêmicas
}

\section{Eduardo Francisco da Silva-Junior ${ }^{1 *}$}

\author{
${ }^{1}$ Departamento de Ecologia, Instituto de Biologia Roberto Alcantara Gomes - IBRAG, \\ Universidade do Estado do Rio de Janeiro - UERJ, Rua São Francisco Xavier, 524, Maracanã, \\ CEP 20550-013, Rio de Janeiro, RJ, Brazil \\ *e-mail: eduardobioadventure@gmail.com
}

Cite as: Silva-Junior, E.F. Land use effects and stream metabolic rates: a review of ecosystem response. Acta Limnologica Brasiliensia, 2016, vol. 28, e10.

Abstract: Aim: To conduct a review of the literature in order to identify the general stream metabolic responses to land use change. Methods: I conducted a scientometric review analyzing the distribution of the studies among different environments, the land use scale used, and the general trends in stream metabolism response under each kind of land-use impact. Major Results: Most of the analyzed studies were conducted in temperate environments, studying land-use impacts at catchment scale. Ecosystem metabolism responded to land use impacts most of the cases, especially under agricultural pressure. The general responses to land-use alterations were increases in rates of Gross Primary Production (GPP) and ecosystem Respiration (R). Primary production increases were mostly related to light and nutrient concentration increases, while $\mathrm{R}$ was usually related to water nutrient concentration, temperature and amount of particulate organic matter, but this general behavior can change under high impact levels where sometimes GPP decreases in response to turbidity increases. Riparian vegetation restoration have a positive effect in driving stream metabolic conditions in the direction of pristine condition, but the effectiveness of this approach is reduced in highly impacted systems. Conclusions: To elucidate the mechanistic relations between stream metabolic changes and land use impacts is still one fundamental aspect to study in order to best predict effects of land use changes and establish management and protection programs. Thus, studies should focus on the causative relations between stream processes and land use changes considering different scales and multiple stress scenarios in order to improve our understanding about factors that drive the observed metabolic changes.

Keywords: stream metabolism; tropical streams; riparian forests; land use; GPP.

Resumo: Objetivo: Conduzir uma revisão da literatura, buscando identificar as respostas gerais do metabolismo de córregos ao impacto de mudanças no uso do solo. Métodos: Eu realizei uma revisão cienciométrica analisando a distribuição dos estudos entre diferentes biomas, as escalas de uso do solo estudadas, e as tendências gerais na resposta do metabolismo de córregos sobre cada tipo de impacto do uso do solo. Resultados Principais: A maioria dos estudos analisados foi realizada em ambientes temperados, estudando os impactos do uso do solo na escala de bacia hidrográfica. O metabolismo ecossistêmico respondeu aos impactos do uso do solo na maioria das vezes, especialmente sobre impacto agrícola. As respostas gerais às alteraçôes no uso do solo foram aumentos na Produção Primaria Bruta (PPB) e Respiração ecossistêmica (R). Aumentos na PPB foram principalmente relacionados com aumentos na disponibilidade de luz e concentração de nutrientes, enquanto a $R$ geralmente foi 
relacionada à concentração de nutrientes, temperatura e quantidade de material orgânico particulado, mas essa tendência geral pode mudar em situaçóes de impacto elevado onde algumas vezes a PPB diminui em resposta a aumentos na turbidez. A restauraçấo da vegetação ripária tem um efeito positivo em conduzir as condiçóes metabólicas de córregos na direção das condiçôes pristinas, mas a efetividade dessa abordagem é reduzida em sistemas altamente impactados. Conclusóes: Elucidar as relaçôes mecanísticas entre mudanças no metabolismo de córregos e impactos do uso do solo continua a ser um dos aspectos fundamentais a serem estudados a fim de melhor prever os efeitos destes impactos e estabelecer estratégias de manejo e proteção. Assim, estudos devem ter como foco as relaçôes causais entre processos ecossistêmicos e mudanças no uso do solo considerando diferentes escalas geográfica e cenários de impactos múltiplos, de forma a aumentar nosso entendimento sobre os fatores que conduzem as mudanças metabólicas observadas.

Palavras-chave: metabolismo de córregos; córregos tropicais; florestas ripárias; uso do solo; PPB.

\section{Introduction}

Expansion of agricultural and urban areas over natural landscapes is a global trend that has been threatening biodiversity and maintenance of ecological processes (Foley et al., 2005). Although they have a relatively small area, lotic environments are especially important in providing environmental services (Postel \& Carpenter, 1997; Naidoo et al., 2008). Rivers and streams provide water, food, energy and many subsidies to agricultural development, and they also have a strong recreational and cultural value. However, these environments have been widely impacted by land-cover changes, agricultural activities, and engineering actions such dams and irrigation channel construction that are used to maximize the access to water as well as to energy production (Meybeck, 2003; Vörösmarty et al., 2010).

Rivers and streams are open ecosystems which are strongly related to the surrounding terrestrial vegetation which in great part determines light and organic matter supply to these ecosystems (Wallace et al., 1999). Riparian areas are extremely important in the maintenance of instream physical structure and diversity of habitats, since it influence aspects such as hydrodynamics, distribution of physical environments, and disturbance intensity (Cummins, 1992). Riparian vegetation has also strong influence on water nutrient concentrations, acting as a biogeochemical filter retaining and transforming part of the nutrients leaching to the stream and also provides resilience to ecosystems during extreme flow events (Hill, 1986; McDowell, 2001).

Changes in riparian land-cover alter stream morphology (Sweeney et al., 2004), organic matter dynamics and water chemistry (Huryn et al., 2002). Such alterations usually spread through ecosystem compartments and lead to changes at the community level, as well as, in ecosystem processes, such nutrient cycling and instream metabolism ("Land cover cascade" sensu Burcher et al., 2007). Moreover, since river basins have a unidirectional nature created by water flux, land use stress factors easily reach the rivers and accumulate downstream (Malmqvist \& Rundle, 2002). Brazilian forest legislation determines that riparian forests should be protected to some extent as "Permanent Protected Areas (APPs)". Recently, legislation changes reduced the width of protected riparian areas in some cases (for example from $30 \mathrm{~m}$ to $5 \mathrm{~m}$ in rural properties smaller than 110 hectares), generating intense political and scientific debates (Nazareno, 2012). However, the discussion was limited by the scarcity of scientific data about the importance of riparian forests to the maintenance of ecosystem processes in tropical lotic ecosystems (Sandin \& Solimini, 2009). There are some demonstrations of the effects of land-use changes on ecosystem processes (Silva-Junior \& Moulton, 2011; Gücker et al., 2009; Silva-Junior et al., 2014) of small rivers in tropical areas, but due the general scarcity and peculiarities of each study, it has been difficult to establish general trends.

Lotic communities are sustained by two different sources of energy; allochthonous matter coming from surrounding terrestrial ecosystems, and biomass production inside the stream (Webster \& Benfield, 1986; Brito et al., 2006). Most of the primary production in headwater streams occurs in periphyton communities driven by algae adhered to the substrates (Allan \& Castillo, 2007). On the other hand, ecosystem respiration considers both autotrophic respiration as well as heterotrophic respiration of the whole system, including all allochthonous material in the stream. The importance of the sources changes along river course, where headwater streams (which usually are more shaded) are more dependent upon allochthonous sources (Vannote et al., 1980). 
However, contrasting to this model developed for temperate streams, food webs of tropical headwater streams appears to rely more on autochthonous algal production (Thorp \& Delong, 2002; Brito et al., 2006).

The balance between overall ecosystem production (Gross primary production - GPP) and community respiration (R) is called "ecosystem metabolism" and represents a functional aspect of the ecosystem, and is related to the biomass production rates that can enter in the aquatic food web (Allan \& Castillo, 2007). Stream ecosystem metabolism is also related to biochemical process such organic matter degradation, which are extremely important for the maintenance of water quality, biodiversity and environmental services. Stream metabolic rates are influenced by many environmental variables such light availability (Bunn et al., 1999), water temperature and nutrient concentration (Mulholland et al., 2001), quantity and quality of organic matter (Acuña et al., 2004), hydrological regime (Uehlinger, 2006) and land use (McTammany et al., 2007; Bernot et al., 2010). In this way, ecosystem metabolism is a key process to be measured when the objective is to evaluate land use impacts in rivers and streams, since it integrates many physical and biological components and is directly related to the surrounding land use (Young et al., 2008; Gücker et al., 2009). However, there are few studies relating stream metabolism to anthropogenic impacts in the tropics, and as different methodologies have been used it becomes more difficult to compare different data.

Stream metabolism is measured based on changes of $\mathrm{O}_{2}$ concentration in the water over time (Hauer \& Lamberti, 2011), applying two groups of methodologies: i) Open-channel methodologies, which are based on global $\mathrm{O}_{2}$ changes in stream water over time under stream natural conditions. ii) Benthic chambers, where $\mathrm{O}_{2}$ changes are measured in microcosms (usually called "benthic chambers") that isolate a certain type of benthic substratum or area of streambed. Open channel methods are divided into the "one-station approach" which calculates metabolism based in the changes in one site, and the "two-station approach" that measures the metabolism of a stream reach (usually hundreds of meters) based on changes in $\mathrm{O}_{2}$ between two sensors (Hauer \& Lamberti, 2011). These open channel methods are usually easy to apply at the field, but have the disadvantage of need for accurate measurements of gas exchanges between water and atmosphere (reaeration). This can be done using different methodologies, such as empirical equations, gas tracer injections, and methods based on nighttime $\mathrm{O}_{2}$ variation (Young \& Huryn, 1996; Iwata et al., 2007). Empirical equations aim to predict reaeration coefficients based on stream morphology (e.g. energy dissipation model described in Hauer \& Lamberti, 2011) and are easy to implement since they use easy to made measurements of water velocity, depth, slope and others. Gas tracer methods analyses de exchange of a tracer gas (usually propane) artificially bubbled into the stream and is usually considered a more reliable technique, but are expensive and time consuming, requiring a lot field and laboratory effort (Grace $\&$ Imberger, 2006). Night-time variation method uses the relation between $\mathrm{O}_{2}$ variation and $\mathrm{O}_{2}$ saturation deficit during the beginning of night. In this period without photosynthesis we can infer that variation in $\mathrm{O}_{2}$ concentration is a function of saturation deficit and then use the slope of this relationship as a reaeration coefficient (Young \& Huryn, 1996).

On the other hand, benthic chambers dispenses with reaeration estimates, but has other difficulties related to the artificiality created by the chamber which limits water and nutrient flux, among other factors. Chambers are especially useful to compare metabolic activity on different substrata types or to experimentally measure the effect of changes in an environmental variable (e.g., nutrient concentration, light availability) on metabolism rates. However, since this methodology is substratum specific it requires replication effort over different substratum types when the objective is to estimate whole system metabolism, what usually is the objective when evaluating land use impacts.

Considering the scarcity of information about land use effects on stream metabolism especially in tropical areas (Bott \& Newbold, 2013; Gücker et al., 2009), the objective of this study was to conduct a review of the literature in order to identify the general stream metabolic responses to land use change. I was trying to elucidate the following questions: i) Where most of the studies take place? ii) Which kinds of impacts have been studied and in which geographic scale? iii) What methodology has been used? iv) Which is the general metabolic response to the different impacts? v) What mechanisms cause the observed changes?

\section{Research Methodology}

I performed a systematic literature review in ISI Web of Science database using the groups of words: "land use" "metabolism", "stream" and "Land use", 
"primary production", "respiration", "stream"), and considering paper of all years. This search found 148 articles, but many of them were studies about land use effects in other environmental features (e.g. macroinvertebrate community, nutrient retention) or presented metabolic estimations of streams but did not related to land use questions. A total of 39 studies were considered relevant to answer the objective questions. I performed an additional search using the words "land use" "metabolism" and "tropical", but no additional paper was found. I added five studies of special relevance to the theme, (Bunn et al., 1999; Mulholland et al., 2005; Bott et al., 2006b; Gücker and Pusch, 2006; Izagirre et al., 2008) that were not found using Web of Science ${ }^{\oplus}$ search. Thus the subsequent analyses were based on 44 papers ranging from 1999 to 2016 . When evaluating the metabolic responses to environmental impacts we considered as "response" just the changes that were deemed by the authors to be statistically significant.

\section{Results}

A summary of the studies analyzed in the scientometric review showing their geographic location, methodology, land cover scale and general stream metabolic responses are present in Table 1. The different environments studied were classified into five main categories (temperate forests, tropical forests, temperate grasslands, tropical savanna, and deserts) where similar biomes were put together. Some studies were carried out in more them one biome and were counted in two or more categories. The study of Bernot et al. (2010) comprised many different environments and was accounted in the categories; Temperate forest, Temperate grassland, Tropical forest, and Desert, and was the only one to present data about this last biome. The work of Young \& Huryn (1999) studied temperate forests and grasslands and was accounted in both categories. Thus the following results are based on 48 case studies.

Studies conducted in temperate environments represented $88.6 \%$ of the study cases (39). Most of the studies were conducted in temperate forests $(33=69 \%)$, and temperate grasslands were studied in $12.5 \%$ (6) of the studies. A minor proportion of the studies present data on tropical environments $(8=16.5 \%)$ with six studies $(12.5 \%)$ presenting data about tropical forest streams and two $(4 \%)$ in Tropical cerrado savanna (Figure 1A).

Most of the research (91\%) used open channel techniques to measure stream metabolism.
The single station open channel approach was the most used technique (53\%) followed by two station open channel approach (26\%) and $5(12 \%)$ studies used both open channel techniques. Only four studies (10\%) used benthic chambers to evaluate land use impacts on stream metabolism (Figure 1B).

The studies evaluated in this work analyzed a wide variety of specific land-use stress and related situations at different scales. Thus to facilitate the following analyses of metabolism responses to the land use modifications, I summarized these studies in four categories related to the nature of the studied stressor: i) Agricultural, that besides crop and pasture land uses also included studies about deforestation and logging, agroforestry management, and others, ii) Urbanization, including studies about point and non-point impacts of this land use, iii) Studies evaluating simultaneously effects of urbanization and agriculture, and iv) Restoration, including studies about effects of benthic, riparian and floodplain restoration. The study of McTammany et al. (2007) evaluated the differences between pristine, agricultural impacted and restored ecosystems, and was included in the categories "restoration" and "agricultural" (thus there were 45 case studies).

Most of the studies $(33=73 \%)$ evaluated the effects of agricultural impacts where $51 \%$ of all works (23) studied only agriculture-related impacts, and 22\% (10) studied impacts of agriculture and urbanization simultaneously (Figure $1 \mathrm{C}$ ). Most of the research studying agricultural impacts $(24=72.7 \%)$ studied non-point effects of agriculture (i.e. diffuse effects such as leaching, temperature increase caused by deforestation) and only one $(2 \%=1)$ studied its point impact, (Rosa et al., 2013, studying effects of a fish farm effluent). Among eight other studies in the category agriculture, four evaluated the effects of deforestation not related to agricultural activity (Houser et al., 2005; Mulholland et al., 2005; Clapcott \& Barmuta, 2010; O'Driscoll et al., 2016), three studied the effects of agroforestry management (Silva et al., 2013; Carlson et al., 2014; Pearce \& Yates, 2015), one evaluated the effects of pesticides and salinity (Schäfer et al., 2012) and other the effects of exotic arboreal vegetation in grassland natural areas (Riley \& Dodds, 2012) (Figure 1C).

Sixteen studies dealt with the effects of urbanization $(37 \%)$, where most of them $(10=23 \%)$ studied it simultaneously with agricultural effects, while only 6 (14\%) studied the urbanization effects alone (Figure 1C). Among all these, 14 studies evaluated non-point effects of 


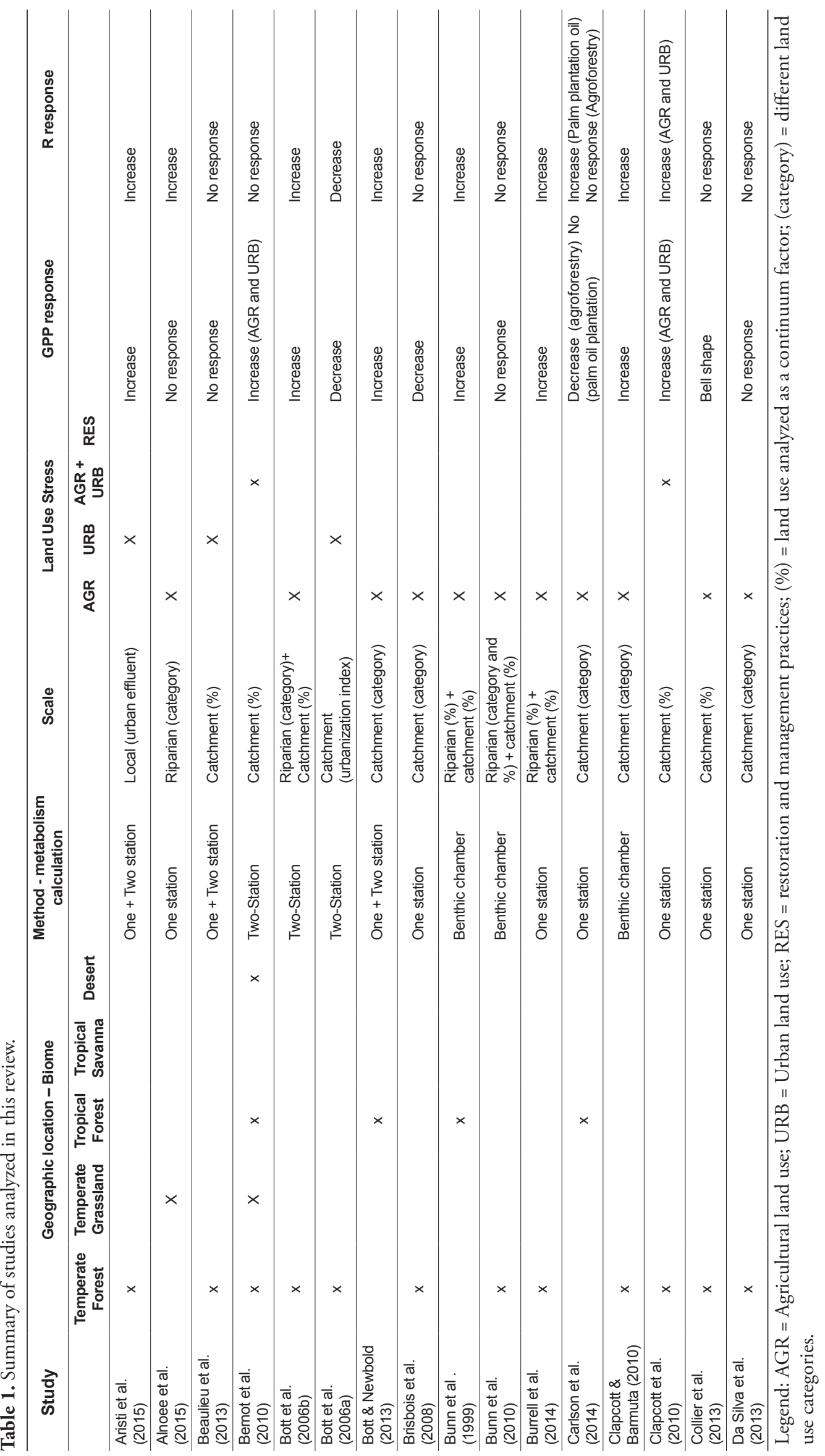




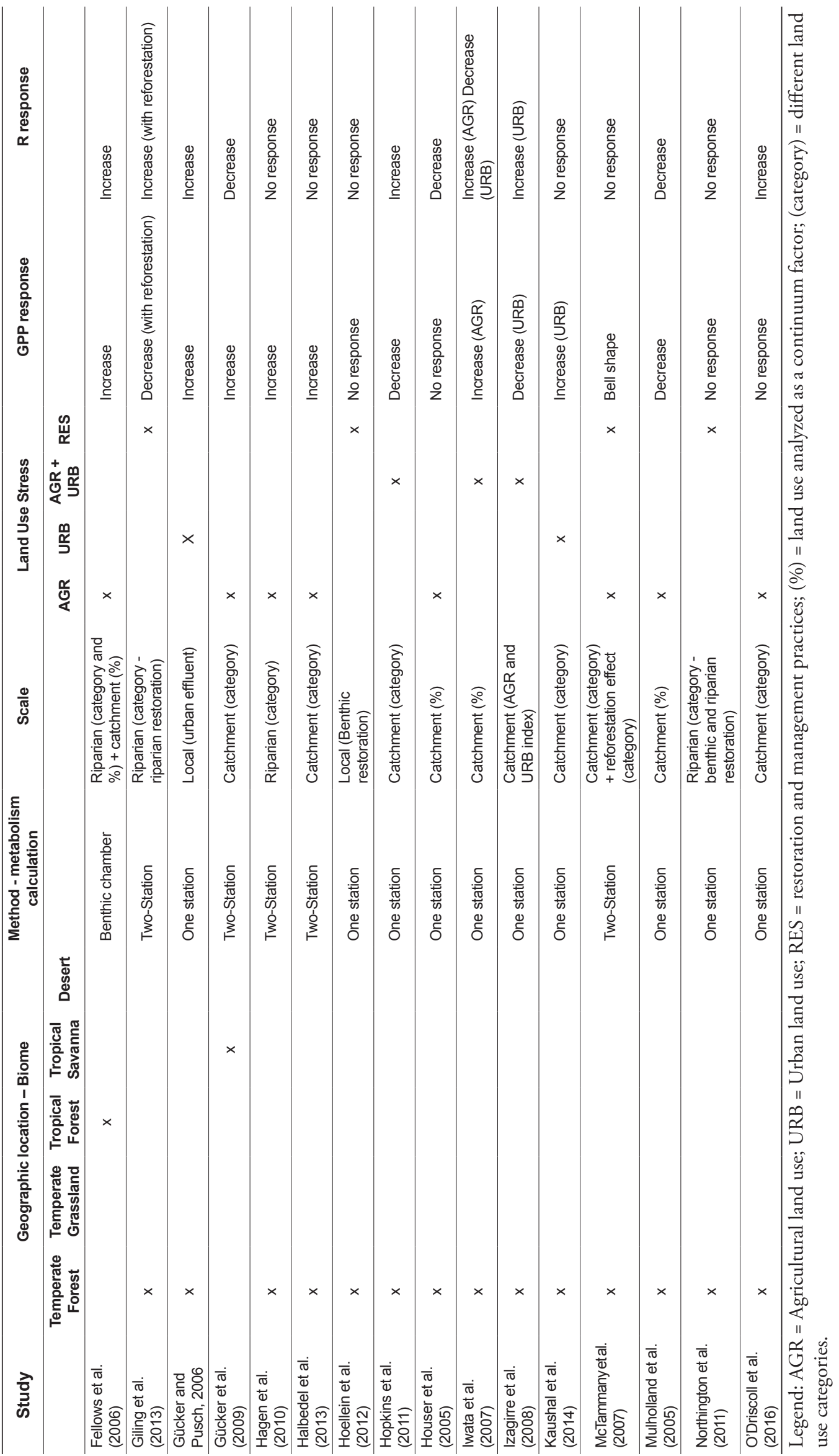




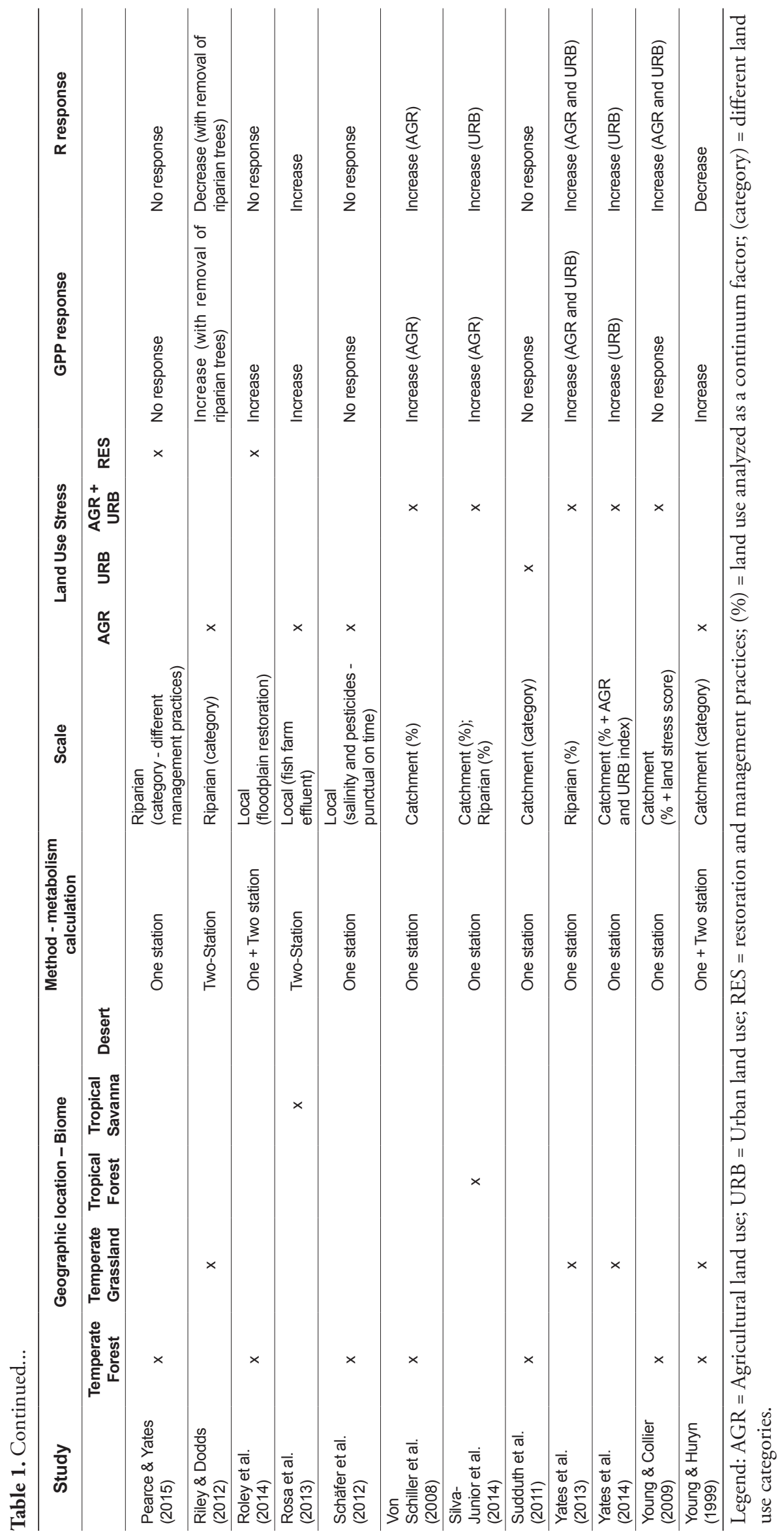


A)

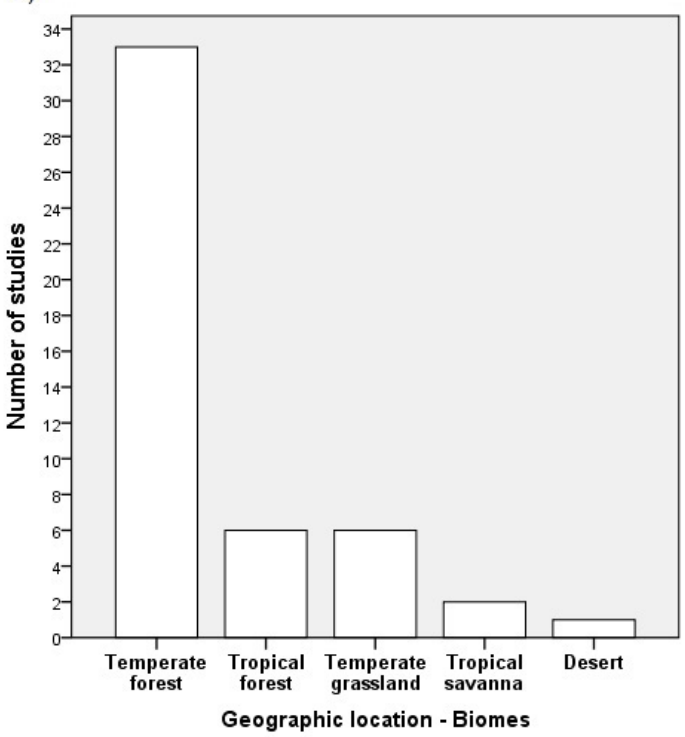

C)

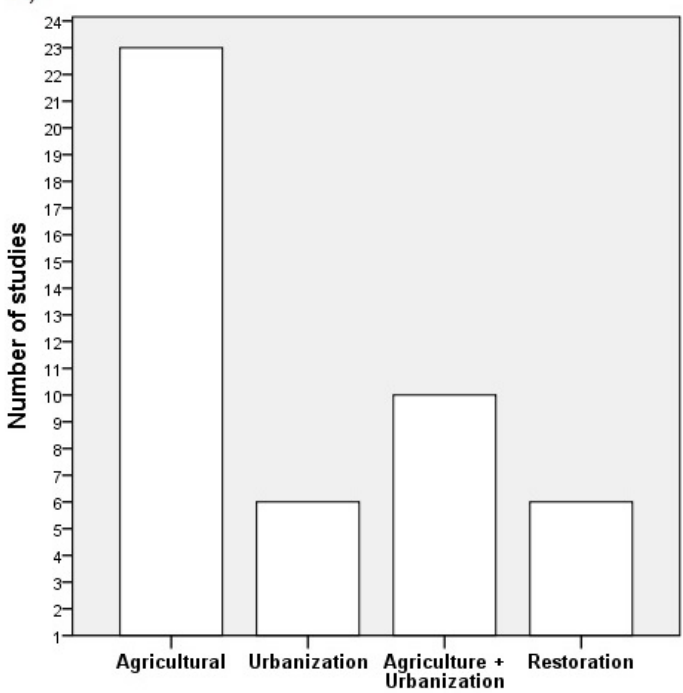

B)

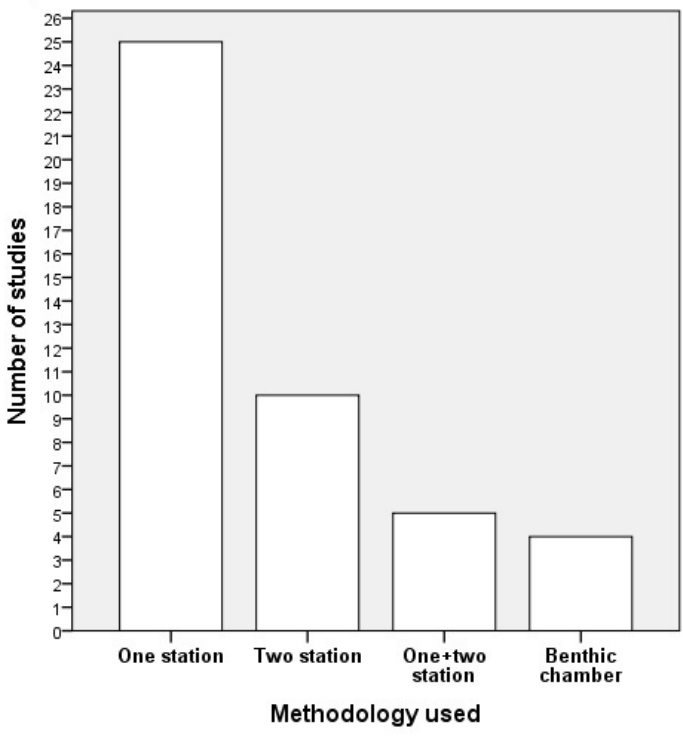

D)

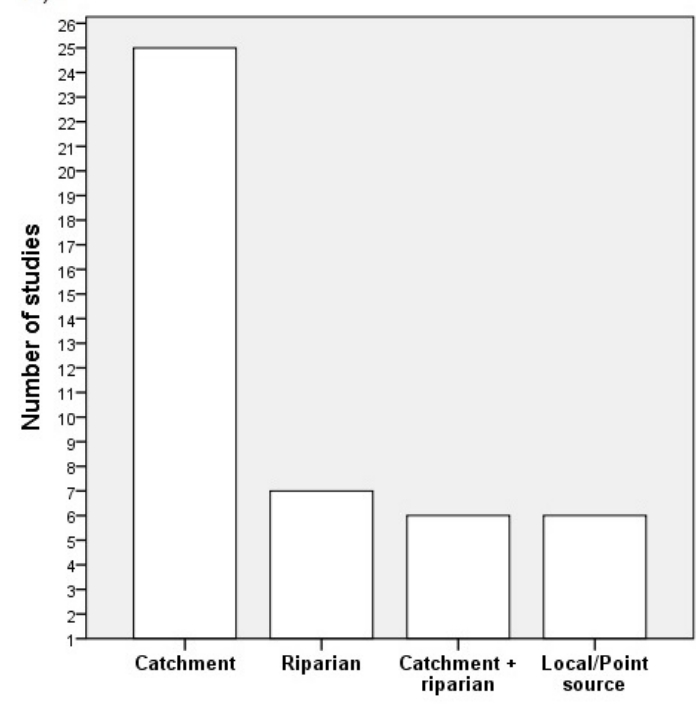

Figure 1. Geographic location (A), methodology used (B), type of land-use impact (C) and geographic scale (D) presented in the analyzed studies.

urbanization (i.e. runoff) and two studies analyzed effects of point stressors related to urbanization (treated domestic sewage effluents). Six (13,3\%) studies evaluated restoration and management practices, where three studied effects of riparian vegetation restoration (McTammany et al., 2007; Giling et al., 2013; Northington et al., 2011) with the last one studying simultaneously riparian and benthic restoration. One study evaluated the effects of riparian management practices (Pearce \& Yates, 2015), while restoration effects of benthic habitat and floodplain area was studied by Hoellein et al. (2012) and Roley et al. (2014) respectively (Figure 1C).
The studies analyzed in this review used different geographic scales as well as different ways of quantifying the land use impacts. Most studied the relation between stream metabolism and land use at catchment scale (31 studies $=70.45 \%$ ), where $25(56.8 \%)$ studied land use effects only at this scale, and six (13.6\%) studied simultaneously catchment and riparian scales (Figure 1D). These studies used different descriptors of catchment land use impacts including proportion of different land use, indices based on these proportions, (Young \& Collier, 2009) and agricultural and urban indices based on human and animal density (Izagirre et al., 2008). Only seven $(15,9 \%)$ studied land-use effects 
on stream metabolism exclusively at riparian scale, so this scale was studied in $29.5 \%$ (13) of the cases (Figure 1D). At this scale the main land-use impact descriptors were percentage of different land uses in riparian corridor (which was also defined in different ways) and percentage of in-stream shading.

Six studies dealt with land-use influence in stream metabolism at local/point-source scale (Figure 1D), including three that studied impacts caused by point-source urban (Gücker and Pusch, 2006; Aristi et al., 2015) and agricultural effluents (Rosa et al., 2013), Tow studies on the effects of habitat restoration (Hoellein et al., 2012; Roley et al., 2014) and one about pesticide application and salinity (Schafer et al., 2012). In this last work the impact was considered point since it occurred just in one short space of time, influencing only a small part of most organisms' life cycle.

Stream metabolism responded to agricultural stress in $85.3 \%$ of the cases (29 studies), and most ( $47 \%=16$ studies) found effects of agricultural land uses in both respiration $(\mathrm{R})$ and primary production (GPP). In this analysis we considered 34 study cases since the work of Carlson et al. (2014) includes two different kinds of agricultural stress (palm oil plantations and rice/fruit garden agroforestry).

When considering only the 29 studies cases that found stream metabolic responses related to agricultural land use, it seems to affect mainly GPP that responded to this stress in $82.8 \%$ (24 studies) of these cases. Three different responses were observed in this parameter; i) increase (+); ii) decrease $(-)$ and a bell-shape response, where an initial increase occurs at low impact levels, followed by a reduction at high impact levels. GPP increased in 62\% (18) of these studies and reductions were observed in only $13.8 \%$ (4), while "bell shape" responses where shown in only $6.8 \%$ (2) of cases. Respiration was less sensitive to agricultural stress and responses were observed in $72.4 \%$ (21) of these cases. Respiration increases occurred in 16 studies (55.2\%) while reductions were observed in only 5 studies (17.2\%). Contrary to GPP no study showed a bell shape response in relation to $\mathrm{R}$ (Figure 2).

Urban land use showed significant influence instream metabolism in $75 \%$ of all cases (12), and in $43.7 \%$ of these (7) land-use stress produced simultaneous changes in both GPP and R rates. Among the twelve studies that showed stream metabolic responses related to urban land use GPP showed changes in $75 \%$ (9) of the cases and the most common response was GPP increases that occurred in 58\% (7) of cases while GPP reductions were found in only $2(17 \%)$. Respiration rates responded to urbanization in $84 \%$ (10) of these studies, with increases in R occurring in 67\% (8) of cases while 2 studies (17\%) showed R reductions (Figure 3).

Stream metabolic parameters showed no predominance in response related to a specific geographic scale, since proportion of overall response in metabolic parameters occurred in each geographic scale were very similar to the proportion of works studying land-use effects at this scale. For example, $30 \%$ of the studies related to agricultural impact studied this at riparian scale
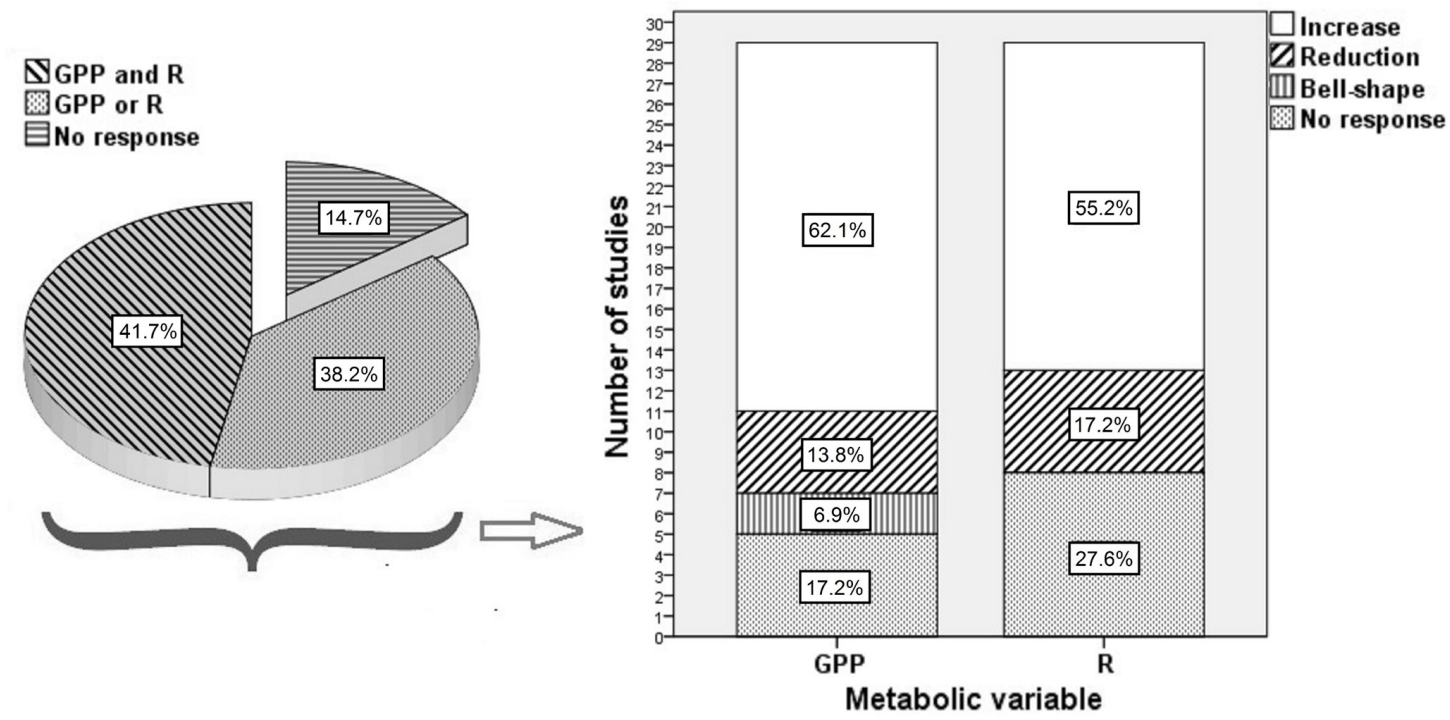

Figure 2. Proportion of studies that found metabolic response related to agricultural land-use (slice chart) and proportion of different responses of GPP and $\mathrm{R}$ found in the responsive studies (bar chart). 

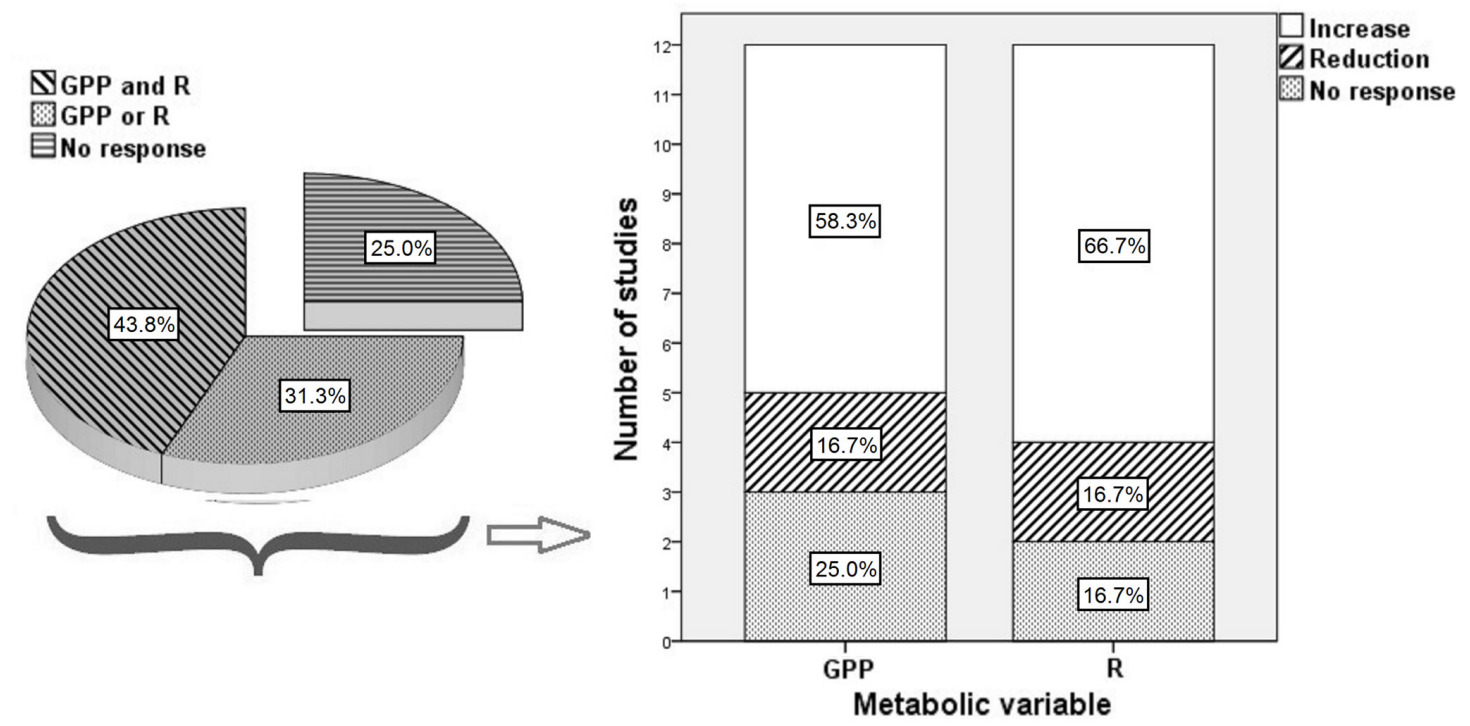

Figure 3. Proportion of studies that found metabolic response related to urban land-use (slice chart) and proportion of different responses of GPP and R found in the responsive studies (bar chart).

and in $31 \%$ there was a response in GPP and 32\% with response in $\mathrm{R}$ the responses occurred at this scale. In a similar way $75 \%$ of the studies related to urban land use impacts used catchment scale, and $\mathrm{GPP}$ and $\mathrm{R}$ responded to the stress at this scale in $67 \%$ of the cases.

Among the six studies evaluating restoration effects, three (McTammany et al., 2007; Northington et al., 2011; Giling et al., 2013) studied the effects of riparian reforestation on stream metabolism. McTammany et al. (2007) and Giling et al. (2013) found reductions in GPP caused by increases in riparian shading, and Giling et al. (2013) also found respiration increases. The work of Northington et al. (2011) tested the effect of riparian and benthic restoration in a highly impacted environment (mine impaired stream), and the authors found no significant changes in stream metabolism after restoration suggesting that it was inefficient to return these highly impacted environments to close to pristine conditions. Pearce $\&$ Yates (2015) evaluated the effects of riparian management practices, such as riparian buffer protection and restrictions to livestock access, in mitigating in-stream effects of agricultural impacts occurring upstream. In this study these practices did not change stream metabolic rates which continued to be very similar to upstream areas were no management practice were done.

Roley et al. (2014) studying the effects of floodplain restoration found increases in GPP and a reduction in its variation after intense flooding events. Hoellein et al. (2012) tested specifically the effect of physical benthic restoration of agricultural streams and found no significant changes in stream metabolism after this kind of restoration.

\section{Discussion}

Most of the analyzed works were carried out in temperate regions, especially in deciduous forest environments, while other environments were very poorly represented. Only two studies (Young \& Huryn, 1999; Bernot et al., 2010) performed comparisons between different environments. The work of Young \& Huryn (1999) showed that streams running through deciduous forests and temperate grasslands are both heterotrophic environments having surprisingly similar metabolic rates with high respiration rates and low primary production. However, under agricultural impact both environments presented a tendency to autotrophy caused by a strong increase in production rates, especially in grassland streams. This work also shows that originally-forested streams running across agriculture and silviculture (exotic pine plantation) land-use areas present very similar increases in GPP and reductions in R. However, the changes were minor when compared with the changes occurring in metabolism of grassland streams under agricultural pressure. The work of Bernot et al. (2010) compared the effects of land-use changes in stream metabolism across different environments, showing that metabolic differences between rivers in different environments (including tropical and deciduous forests, temperate grasslands and deserts) 
tended to be reduced after anthropogenic impact (agriculture and urbanization), which occurred mainly by GPP increases that led the streams in general to a less heterotrophic situation.

Only eight works studied land-use influence in tropical streams (including Bernot et al., 2010). These studies were conducted in tropical forests and cerrado savanna streams and showed similar metabolic responses among environments where the most common response was GPP and R increases after anthropogenic impact. Gücker et al. (2009) studying streams in a cerrado area found that agricultural stress increased respiration rates per area of heterotrophic biofilm, but agricultural impact also led to physical stress causing a strong reduction in biofilm biomass leading to an overall reduction in $\mathrm{R}$ rates. The same study also found that GPP increases related to agricultural activity were rather caused by an increased in photosynthetic efficiency than by autotrophic biomass increase. Bott \& Newbold (2013) working in Peruvian rainforest also found 2-fold GPP increases, but probably the photosynthetic efficiency was reduced since algal biomass increased 8 fold. Contrary to this, Carlson et al. (2014) apparently working with relative low levels of agricultural anthropogenic impact (agroforestry and palm oil plantations Elaeis guineensis - that maintain riparian shading and allochthonous matter input similar to pristine conditions) found a small reduction in GPP associated to traditional agroforestry management (rice and fruit garden) but no change associated with palm oil plantations. In another direction, the same study found an increase in respiration rates in palm oil culture that did not occur in agroforestry environments. This respiration increase could be driven by elevation in stream water temperature that was registered in palm oil areas. Silva Junior et al. (2014) working in Atlantic rainforest/cerrado transition area, found respiration increases related to low level of urbanization that was probably driven by nitrogen enrichment. Rosa et al. (2013) studying impact of small fish-farm effluent in streams in the same region also found strong respiration increase that in this case was related to nutrient enrichment and amount of particulate organic matter.

Most of the studies measured stream metabolism using open-channel techniques, especially the single station approach. Usually open channel methods are considered more suitable for measuring whole-system effects of land use stress (Grace \& Imberger, 2006), since they measure the whole system metabolism and not just a specific substratum. Open channel methods are also easy to implement, especially in catchment scale studies. However, the open-channel approach requires good reaeration estimates, and as was demonstrated by Iwata et al. (2007) different techniques to estimate reaeration can lead to different results.

Only three studies used both open channel methods. Beaulieu et al. (2013) found strong agreement between "one station" and "two station" approaches, while Roley et al. (2014) found smaller values of GPP using the two station approach, which the authors attributed to a smaller reach size measured in this approach compared to the estimated reach size measured using the one-station approach in that specific situation. Young \& Huryn (1999) also found small differences between methods where the two-station approach resulted in higher $\mathrm{R}$ rates, but this difference did not have appreciable effect in the GPP/R ratios. Thus, including considerations about reach size measured by each method in each specific situation, both open channel approaches seem to have strong concordance.

Benthic chambers usually provide a more reliable measure of oxygen metabolism, especially in high turbulent small streams, since it is not influenced by reaeration. Chamber are especially useful to analyses whether different substrates types (i.e. sand, rock) respond different to a metabolic change trigged by land use alteration (Grace $\&$ Imberger, 2006). However, due its restriction to specific substratum types is necessary a good replication in different substratum types especially when this substrates is very heterogeneous. This need for replication can make the use of benthic chamber to evaluate land use effects very expensive and time consuming, limiting its appliance. There also some criticisms about artificiality introduced by the chamber which can cause nutrient depletion and temperature change (Hauer \& Lamberti, 2011), introducing other sources of errors in metabolic measures.

The largest proportion of the analyzed studies evaluated effects of agriculture and urbanization, especially those related to non-point source of stress, however different ways of evaluating land use and anthropogenic pressure were applied. In general, vegetation land-cover evaluation using satellite images was the most common descriptor of land use impact. Young \& Collier (2009) used a variation of this approach that attributed different weights to different land-use categories and Izagirre et al. (2008) used industrialization percentage and human and livestock density as indicators of land 
use pressure. Yates et al. (2014) tested the responses of many ecological variables to different kinds of anthropogenic pressure descriptors including land cover descriptors, agriculture and livestock production numbers, as well as those related to farm-management practices. In this study, different kinds of ecological variables showed specificity in the response to stress indicators, and usually were sensitive to just one or few anthropogenic pressure descriptors.

Between works studying effects of habitat restoration, the work of Roley et al. (2014) evaluate the effects of flood plain restoration, show that this slow flux areas can increase GPP by creating and turn metabolic parameters more stable after flood events, but had no effect during base flow conditions. In a similar way Aristi et al. (2014) (not accounted in this review) found that dams can increase both GGP and R downstream. The authors argue that dams create more suitable environments for algae and macrophyte development thus increasing GGP rates. It could in a limited extent conducted to the increase in respiration rates, but in this study $\mathrm{R}$ increases were even bigger that GGP ones, and probably $\mathrm{R}$ increases were driven by temperature increases.

McTammany et al. (2007) and Giling et al. (2013) found that riparian vegetation restoration was efficient in changing stream metabolic parameters in the direction of what was expected for a pristine situation. However, in the study of Pearce \& Yates (2015) management practices such as, restriction of livestock access to stream channel, maintenance of riparian buffers in limited areas, and others, did not change the metabolic parameters of the studied agricultural streams and management practices were considered inefficient in change metabolic parameters. Similarly, Northington et al. (2011) did not find recovery of metabolic parameters in rivers impacted by mine activity after riparian and benthic habitat restoration, but in this study almost all restored sites had less than 10 years of restoration and authors argued that probably a further riparian development will probably conduct to metabolic modification.

Benthic restoration effects were also studied by Hoellein et al. (2012) and also showed no appreciable effects in stream metabolic rates in agricultural impacted streams. In this study the authors hypothesized that Increases in gravel, cobble and boulder habitat artificially introduced by restoration process will lead to an increase in metabolic rates, since a similar relation was found in a previous study (Hoellein et al., 2007) and lead to predictions that the manipulation of benthic habitat would alter rates of ecosystem function. However, its seems that restoration of these features do not conducted to whole system changes in metabolism, since its effects overwhelmed by riparian condition effects. This way, these works seem to indicate that riparian vegetation restoration is the most important factor in restoring stream metabolic rates close to pristine conditions, however even this approach can be of limited application in highly impacted systems.

There was a predominance of studies using catchment geographic scale, and fewer studies evaluating the relation between stream metabolism and riparian vegetation. Among the thirteen publications evaluating land use effects at the riparian scale, four (Bunn et al., 1999, 2010; Fellows et al., 2006; Burrell et al., 2014) considered stream shading caused by riparian vegetation as a riparian land use descriptor. However, shading does not correspond to a real riparian land use measure, since it does not give any information about riparian buffer extent or structure, and is strongly influenced by local conditions, which depend on stream size and width. Besides this, it is inadequate to evaluate riparian use in naturally open landscapes. In the study of Pearce \& Yates (2015) on the effects of management practices were applied indices based on the presence and extent of different management practices, so this study also used an indirect measure of riparian impact (restoration in this case). It is surprisingly the scarcity of studies focused on land-use effects at the riparian scale, since the close relation between river metabolic balance and its surrounding vegetation has been discussed for a long time (e.g. Vannote et al., 1980). Some indirect inferences on the effects of riparian change in stream metabolism can be done, since many studies show responses in structural components expected to be strong related to stream metabolism, especially modifications in benthic algae biomass and grazer invertebrates abundance (Dance \& Hynes, 1980; Delong \& Brusven, 1998; Sponseller et al., 2001). However, extrapolations should be done carefully, since the understanding of the relation between structure and function is considered one of the greatest challenges of ecology science nowadays (Sandin \& Solimini, 2009), and there are scarcity of experimental data about this relationship.

Measurable metabolic changes under land-use stress occurred in most of the analyzed studies, especially in those studying streams under 
agricultural impacts. In more than half the cases these changes occurred in both metabolic rates. In general GPP rates seem to be more sensitive to agricultural impacts showing alterations related to agricultural stress in $82.8 \%$ of all responsive studies, where usually there were increases in GPP rates that were in general related to light and nutrient increases. In some cases GPP showed measurable response even in low impact levels as in the study of Halbedel et al. (2013), where percentage of impacted area in the analyzed catchment varied only $7-17 \%$, and riparian forests were always present. Studying the effects of non-native arboreal vegetation Riley \& Dodds (2012) found the same general trend occurring in an opposite direction since this exotic vegetation reduced GPP by shading. Contrary to these general results, some studies showed GPP reductions associated with agricultural land use. Brisbois et al. (2008) and Hopkins et al. (2011) attributed these GPP reductions to an elevated turbidity associated with high levels of agricultural use in the studied catchment. Hopkins et al. (2011) also found respiration increases which can corroborate this idea since $\mathrm{R}$ increases are expected if more suspended solids are present in the water column. Moreover, Yates et al. (2013) found differences in metabolic responses in streams impacted by agriculture and animal husbandry, where agriculture stimulated GPP and animal husbandry activity was related to GPP reductions. In this study it was possible that there was an effect of livestock crossing the river and grazing on riparian areas which increased turbidity and impacted streambed.

Assessing deforestation effects (as proportion of naked soil varying between $1.8-13 \%$ ) at catchment scale, Mulholland et al. (2005) verified GPP reductions associated with this impact. In this case, riparian vegetation remained unaltered and probably the observed reductions occurred as effects of increase in turbidity caused by leaching in the areas without any vegetation cover. Studying the same streams, Houser et al. (2005) found reductions in $\mathrm{R}$ rates, which could happen as a consequence of reductions in autotrophic respiration or in the amount of organic matter received by the stream. Similarly the study of Carlson et al. (2014) showed small GPP reductions in stream metabolism associated with traditional agroforestry management (rice farm and fruit gardens), but palm oil plantations did not have measurable effects on GPP rates. In this study the in-stream shading was at least in part maintained, which probably controlled
GPP increases and the observed reductions could be also a turbidity effect. Silva et al. (2013) found that selective logging in the catchment where a 15-m buffer zone was respected and where riparian vegetation was integrally preserved had no effect on stream metabolic rates. The studies of McTammany et al. (2007) and Collier et al. (2013) found initial increases in GPP under low impact levels followed by GPP reductions in high levels of agricultural impacts. Similarly to the studies mentioned above, these GPP reductions in high impact levels seem to be related to turbidity increases caused by livestock activity in the stream channel.

In general respiration rates seem to be less sensitive to agricultural impacts, and the most common response was increases in respiration rates. These results are unexpected, since reductions were expected as consequence of reductions in allochthonous organic matter received by streams running through agricultural landscapes. In some cases (Burrell et al., 2014) there was even an unexpected negative relationship between riparian shading and $\mathrm{R}$ rates. Some studies (Von Schiller et al., 2008; Yates et al., 2013) found a strong relationship between GPP and R indicating that to some extent respiration increases can occur as consequence of autotrophic respiration increase rather than heterotrophic respiration. However the explanation provided by this mechanism can explain only a part of the R increase. Many authors (Hopkins et al., 2011; Rosa et al., 2013; Bott \& Newbold, 2013) argue that $\mathrm{R}$ increases under agricultural stress could be caused by stimulation in heterotrophic metabolism caused by increases in temperature and nutrient concentration in stream water. Another possibility proposed by Bott et al. (2006b) and Clapcott \& Barmuta (2010), is that these respiration increases could occur due to increases in hyporheic respiration as a consequence of organic matter burial caused by siltation.

Urban land use also influences stream metabolism in most of the cases. Under this kind of stress $\mathrm{R}$ seems to be slight more affected than GPP and the main response was increases in both variables rates. Production increases were most of the times attributed to increases in nutrient concentration, especially ammonia (Gücker \& Pusch, 2006; Bernot et al., 2010; Clapcott et al., 2010; Kaushal et al., 2014). However, some studies found GPP reductions in streams running across urban land-use areas. In the study of Bott et al. (2006a) GPP was lower 
in the most urbanized catchment despite its higher ammonium concentration. In this study the authors argue that instead of urbanization in the catchment area, most of the riparian shading was maintained and this limited production. Iwata et al. (2007) studying highly-urbanized catchments also found GPP reduction that could have been the effect of the highly impacted levels, similar to the GPP reduction relationship to agricultural stress. Respiration rates also increased with urban land use and were many times related to nutrient concentration (Clapcott et al., 2010; Izagirre et al., 2008; Silva-Junior et al., 2014) and labile carbon increases (Gücker \& Pusch, 2006). In only two cases R reductions were observed (Bott et al., 2006a; Iwata et al., 2007). Bott et al. (2006a) attributed this response to its strong linkage with GPP (that also diminished in this study), while Iwata et al. (2007) argue that it could be an effect of reductions in the amount of organic carbon arriving in the stream.

It is important to underline that instead of the apparently smaller response of stream metabolism to urban land use when comparing with agricultural impacts, usually studies of urban land-use stress evaluated effects of relatively low level of impact. For example, Clapcott et al. (2010) found stream responses in GPP and $\mathrm{R}$ even working with minimum levels of disturbance at catchment scale $(<10 \%$ of urbanization) and Silva-Junior et al. (2014) found responses in $\mathrm{R}$ considering riparian land use scale and even smaller level of urbanization ( $8 \%$ maximum). Theoretically stream metabolism should be more sensitive to impacts at the riparian scale, however in the revised works there was not any evident relationship between metabolic responses and the scale tested, since apparently the proportions of responses in one given scale is very close to the proportion in which that scale was used. However the scale dependency is difficult to analyze in these cases since different indicators are used to describe a specific kind of impact in a given scale, (e.g. population density $\times$ urban land cover, or riparian land cover $\times$ instream shading). Moreover, it is extremely difficult to separate effects related to riparian scale from those related to catchment scale, since regardless of the scale tested in a given study, in most of the cases land-use impacts existed in more than one scale at the same time.

\section{Conclusions}

There is scarcity of studies relating effects of land use in stream metabolism in tropical areas and studies in temperate biomes were almost 5 times more abundant in this review. This is particularly worrying since these are the areas suffering more intense land use modifications nowadays. Usually studies are conducted in catchment scale and with less research assessing land use effects at the riparian scale that theoretically should have a more strong relation to in-stream process. However, among analyzed studies there was no evidence of preferential metabolic responses related to a specific scale.

Stream metabolism responded to land-use impacts in most of the cases, showing that this fundamental process is considerably affected by land use. Metabolic rates usually increase with agriculture and urbanization; GPP rates seem to be mainly driven by light and nutrient increases. Among the analyzed cases, nutrient concentration should play a very important role since GPP increases were observed even in cases where riparian shading was maintained and in naturally open landscapes such cerrado savanna and temperate grasslands, so in these environments nutrient increases may be a key factor controlling GPP. However, instead of the GPP increase being the common response, high level of impact can cause increase in the amount of suspended solids in the water and streambed alterations which reduce GPP by light limitation or by partially excluding algae and macrophytes. Unexpected respiration rate increases should probably be partially influenced by high importance of the autotrophic growth in these systems. However, it is also highly probably that inconspicuous allochthonous carbon sources, such leached fine sediments, can be a strong influence, as well as elevated nutrient concentration which could be stimulate heterotrophic metabolism. Agroforestry management practices seem to cause minimal effects on stream metabolic rates and restoration programs based on riparian vegetation recovery seems to be efficient in driving metabolic rates of impacted streams in the direction of a more natural condition. However efficiency of this approach seems to be dependent of the impact level.

To elucidate the specific mechanistic relations between stream metabolic changes and land use impacts is still one fundamental aspect to elucidate in order to best predict effects of land use changes and establish management and protection programs, but it has been difficult since impacted streams are usually under multiple stress scenarios. Moreover, instead of some ecosystem aspects being theoretically more related to a specific scale, frequently land use impacts take place in different 
scales at the same time. Thus, studies of the causative relations between stream processes and land use changes which consider different scales are fundamental to provide better explanations about the key factors that drive the observed instream metabolic changes.

\section{Acknowledgements}

I thank Timothy Peter Moulton and Rafael Feijó de Lima to performed English review of this work and to Coordenação de Aperfeiçoamento de Pessoal de Nível Superior (CAPES) for providing my $\mathrm{PhD}$ fellowship.

\section{References}

ACUÑA, V., GIORGI, A., MUÑOZ, I., UEHLINGER, U. and SABATER, S. Flow extremes and benthic organic matter shape the metabolism of a headwater Mediterranean stream. Freshwater Biology, 2004, 49(7), 960-971. http://dx.doi.org/10.1111/j.13652427.2004.01239.x.

ALLAN, J.D. and CASTILLO, M.M. (2007). Stream ecology: structure and function of running waters. 2nd ed. Netherlands: Springer Science \& Business Media Springer, $436 \mathrm{p}$.

ALNOEE, A.B., RIIS, T., ANDERSEN, M.R., BAATTRUP-PEDERSEN, A. and SANDJENSEN, K. Whole-stream metabolism in nutrientpoor calcareous streams on Öland, Sweden. Aquatic Sciences, 2015, 77(2), 207-219. http://dx.doi. org/10.1007/s00027-014-0380-5.

ARISTI, I., ARROITA, M., LARRAÑAGA, A., PONSATÍ, L., SABATER, S., VON SCHILLER, D., ELOSEGI, A. and ACUÑA, V. Flow regulation by dams affects ecosystem metabolism in Mediterranean rivers. Freshwater Biology, 2014, 59(9), 1816-1829. http://dx.doi.org/10.1111/fwb.12385.

ARISTI, I., VON SCHILLER, D., ARROITA, M., BARCELÓ, D., PONSATÍ, L., GARCÍA-GALÁN, M.J., SABATER, S., ELOSEGI, A. and ACUÑA, V. Mixed effects of effluents from a wastewater treatment plant on river ecosystem metabolism: subsidy or stress? Freshwater Biology, 2015, 60(7), 1398-1410. http://dx.doi.org/10.1111/fwb.12576.

BEAUliEU, J.J., ARANGO, C.P., BALZ, D.A. and SHUSTER, W.D. Continuous monitoring reveals multiple controls on ecosystem metabolism in a suburban stream. Freshwater Biology, 2013, 58(5), 918-937. http://dx.doi.org/10.1111/fwb.12097.

BERNOT, M.J., SOBOTA, D.J., HALL, R.O. Jr., MULHOLLAND, P.J., DODDS, W.K., WEBSTER, J.R., TANK, J.L., ASHKENAS, L.R., COOPER, L.W., DAHM, C.N., GREGORY, S., GRIMM, N.B., HAMILTON, S.K., JOHNSON, S.L., MCDOWELL, W.H., MEYER, J.L.,
PETERSON, B., POOLE, G.C., VALETT, H.M., ARANGO, C., BEAULIEU, J.J., BURGIN, A.J., CRENSHAW, C., HELTON, A.M., JOHNSON, L., MERRIAM, J., NIEDERLEHNER, B.R., O'BRIEN, J.M., POTTER, J.D., SHEIBLEY, R.W., THOMAS, S.M. and WILSON, K. Inter-regional comparison of land-use effects on stream metabolism. Freshwater Biology, 2010, 55(9), 1874-1890. http:// dx.doi.org/10.1111/j.1365-2427.2010.02422.x.

BOTT, T.L. and NEWBOLD, J.D. Ecosystem metabolism and nutrient uptake in Peruvian headwater streams. International Review of Hydrobiology, 2013, 98(3), 117-131. http://dx.doi. org/10.1002/iroh.201201612.

BOTT, T.L., MONTGOMERY, D.S., NEWBOLD, J.D., ARSCOTT, D.B., DOW, C.L., AUFDENKAMPE, A.K., JACKSON, J.K. and KAPLAN, L.A. Ecosystem metabolism in streams of the Catskill Mountains (Delaware and Hudson River watersheds) and Lower Hudson Valley. Journal of the North American Benthological Society, 2006a, 25(4), 1018-1044. http://dx.doi.org/10.1899/08873593(2006)025[1018:EMISOT]2.0.CO;2.

BOTT, T.L., NEWBOLD, J.D. and ARSCOTT, D.B. Ecosystem metabolism in Piedmont streams: reach geomorphology modulates the influence of riparian vegetation. Ecosystems, 2006b, 9(3), 398-421. http:// dx.doi.org/10.1007/s10021-005-0086-6.

BRISBOIS, M.C., JAMIESON, R., GORDON, R., STRATTON, G. and MADANI, A. Stream ecosystem health in rural mixed land-use watersheds. Journal of Environmental Engineering and Science, 2008, 7(5), 439-452. http://dx.doi.org/10.1139/ S08-016.

BRITO, E.F., MOULTON, T.P., SOUZA, M.L. and BUNN, S.E. Stable isotope analysis indicates microalgae as the predominant food source of fauna in a coastal forest stream, south-east Brazil. Austral Ecology, 2006, 31(5), 623-633. http://dx.doi. org/10.1111/j.1442-9993.2006.01610.x.

BUNN, S.E., ABAL, E.G., SMITH, M.J., CHOY, S.C., FELLOWS, C.S., HARCH, B.D., KENNARD, M.J. and SHELDON, F. Integration of science and monitoring of river ecosystem health to guide investments in catchment protection and rehabilitation. Freshwater Biology, 2010, 55(s1), 223-240. http://dx.doi.org/10.1111/j.13652427.2009.02375.x.

BUNN, S.E., DAVIES, P.M. and MOSISCH, T.D. Ecosystem measures of river health and their response to riparian and catchment degradation. Freshwater Biology, 1999, 41(2), 333-345. http://dx.doi. org/10.1046/j.1365-2427.1999.00434.x.

BURCHER, C.L., VALETT, H.M. and BENFIELD, E.F. The land-cover cascade: relationships coupling land and water. Ecology, 2007, 88(1), 228-242. http:// 
dx.doi.org/10.1890/0012-9658(2007)88[228:TLCR CL]2.0.CO;2. PMid:17489471.

BURRELL, T.K., O’BRIEN, J.M., GRAHAM, S.E., SIMON, K.S., HARDING, J.S. and MCINTOSH, A.R. Riparian shading mitigates stream eutrophication in agricultural catchments. Freshwater Science, 2014, 33(1), 73-84. http://dx.doi.org/10.1086/674180.

CARLSON, K.M., CURRAN, L.M., PONETTEGONZÁLEZ, A.G., RATNASARI, D., RUSPITA., LISNAWATI, N., PURWANTO, Y., BRAUMAN, K.A. and RAYMOND, P.A.Influence of watershedclimate interactions on stream temperature, sediment yield, and metabolism along a land use intensity gradient in Indonesian Borneo. Journal of Geophysical Research. Biogeosciences, 2014, 119(6), 1110-1128. http://dx.doi.org/10.1002/2013JG002516.

CLAPCOTT, J.E. and BARMUTA, L.A. Forest clearance increases metabolism and organic matter processes in small headwater streams. Journal of the North American Benthological Society, 2010, 29(2), 546-561. http://dx.doi.org/10.1899/09-040.1.

CLAPCOTT, J.E., YOUNG, R.G., GOODWIN, E.O. and LEATHWICK, J.R. APPLIED ISSUES: Exploring the response of functional indicators of stream health to land-use gradients. Freshwater Biology, 2010, 55(10), 2181-2199. http://dx.doi. org/10.1111/j.1365-2427.2010.02463.x.

COLLIER, K.J., CLAPCOTT, J.E., HAMER, M.P. and YOUNG, R.G. Extent estimates and land cover relationships for functional indicators in nonwadeable rivers. Ecological Indicators, 2013, 34, 53-59. http://dx.doi.org/10.1016/j.ecolind.2013.04.010.

CUMMINS, K.W. (1992). Catchment characteristics and river ecosystems. In: P.J. BOON, P. CALOW and G.E. PETTS, eds. River conservation and management. Chichester: John Wiley and Sons, pp. $125-135$.

DANCE, K.W. and HYNES, H.B.N. Some effects of agricultural land use on stream insect communities. Environmental Pollution. Series A. Ecological and Biological, 1980, 22(1), 19-28. http://dx.doi. org/10.1016/0143-1471(80)90078-1.

DELONG, M.D. and BRUSVEN, M.A. Macroinvertebrate community structure along the longitudinal gradient of an agriculturally impacted stream. Environmental Management, 1998, 22(3), 445-457. http://dx.doi.org/10.1007/ s002679900118. PMid:9516536.

FELLOWS, C., CLAPCOTT, J., UDY, J., BUNN, S., HARCH, B., SMITH, M. and DAVIES, P. Benthic metabolism as an indicator of stream ecosystem health. Hydrobiologia, 2006, 572(1), 71-87. http:// dx.doi.org/10.1007/s10750-005-9001-6.

FOLEY, J.A., DEFRIES, R., ASNER, G.P., BARFORD, C., BONAN, G., CARPENTER, S.R., CHAPIN, F.S., COE, M.T., DAILY, G.C., GIBBS, H.K.,
HELKOWSKI, J.H., HOLLOWAY, T., HOWARD, E.A., KUCHARIK, C.J., MONFREDA, C., PATZ, J.A., PRENTICE, I.C., RAMANKUTTY, N. and SNYDER, P.K.. Global consequences of land use. Science, 2005, 309(5734), 570-574. http://dx.doi. org/10.1126/science.1111772. PMid:16040698.

GILING, D.P., GRACE, M.R., MAC NALLY, R. and THOMPSON, R.M. The influence of native replanting on stream ecosystem metabolism in a degraded landscape: can a little vegetation go a long way? Freshwater Biology, 2013, 58(12), 2601-2613. http://dx.doi.org/10.1111/fwb.12236.

GRACE, M. and IMBERGER, S. Stream metabolism: performing \& interpreting measurements. Melbourne: Water Studies Centre, Monash University, Darling Basin Commission, 2006. vol. 204. Report for the Murray.

GÜCKER, B. and PUSCH, M.T. Regulation of nutrient uptake in eutrophic lowland streams. Limnology and Oceanography, 2006, 51(3), 1443-1453. http:// dx.doi.org/10.4319/lo.2006.51.3.1443.

GÜCKER, B., BOECHAT, I.G. and GIANI, A. Impacts of agricultural land use on ecosystem structure and whole-stream metabolism of tropical Cerrado streams. Freshwater Biology, 2009, 54(10), 2069-2085. http://dx.doi.org/10.1111/j.13652427.2008.02069.x.

HAGEN, E.M., MCTAMMANY, M.E., WEBSTER, J.R. and BENFIELD, E.F. Shifts in allochthonous input and autochthonous production in streams along an agricultural land-use gradient. Hydrobiologia, 2010, 655(1), 61-77. http://dx.doi.org/10.1007/ s10750-010-0404-7.

HALBEDEL, S., BÜTTNER, O. and WEITERE, M. Linkage between the temporal and spatial variability of dissolved organic matter and whole-stream metabolism. Biogeosciences, 2013, 10(8), 5555-5569. http://dx.doi.org/10.5194/bg-10-5555-2013.

HAUER, F.R. and LAMBERTI, G.A., eds. Methods in stream ecology. New York: Academic Press, 2011.

HILL, A.R. Stream nitrate-N loads in relation to variations in annual and seasonal runoff regimes. Journal of the American Water Resources Association, 1986, 22(5), 829-839. http://dx.doi. org/10.1111/j.1752-1688.1986.tb00757.x.

HOELLEIN, T.J., TANK, J.L., ENTREKIN, S.A., ROSI-MARSHALL, E.J., STEPHEN, M.L. and LAMBERTI, G.A. Effects of benthic habitat restoration on nutrient uptake and ecosystem metabolism in three headwater streams. River Research and Applications, 2012, 28(9), 1451-1461. http:// dx.doi.org/10.1002/rra.1547.

HOELLEIN, T.J., TANK, J.L., ROSI-MARSHALL, E.J., ENTREKIN, S.A. and LAMBERTI, G.A. Controls on spatial and temporal variation of nutrient uptake in three Michigan headwater streams. 
Limnology and Oceanography, 2007, 52(5), 19641977. http://dx.doi.org/10.4319/lo.2007.52.5.1964.

HOPKINS, J.M., MARCARELLI, A.M. and BECHTOLD, H.A. Ecosystem structure and function are complementary measures of water quality in a polluted, spring-influenced river. Water, Air, and Soil Pollution, 2011, 214(1-4), 409-421. http://dx.doi.org/10.1007/s11270-010-0432-y.

HOUSER, J.N., MULHOLLAND, P.J. and MALONEY, O.K. Catchment disturbance and stream metabolism: patterns in ecosystem respiration and gross primary production along a gradient of upland soil and vegetation disturbance. Journal of the North American Benthological Society, 2005, 24(3), 538-552. http://dx.doi.org/10.1899/04-034.1.

HURYN, A.D., BUTZ HURYN, V.M., ARBUCKLE, C.J. and TSOMIDES, L. Catchment land-use, macroinvertebrates and detritus processing in headwater streams: taxonomic richness versus function. Freshwater Biology, 2002, 47(3), 401-415. http://dx.doi.org/10.1046/j.13652427.2002.00812.x.

IWATA, T., TAKAHASHI, T., KAZAMA, F., HIRAGA, Y., FUKUDA, N., HONDA, M., KIMURA, Y., KOTA, K., KUBOTA, D., NAKAGAWA, S., NAKAMURA, T., SHIMURA, M., YANAGIDA, S., XEU, L., FUKASAWA, E., HIRATSUKA, Y., IKEBE, T., IKENO, N., KOHNO, A., KUBOTA, K., KUWATA, K., MISONOU, T., OSADA, Y., SATO, Y., SHIMIZU, R. and SHINDO, K. Metabolic balance of streams draining urban and agricultural watersheds in central Japan. Limnology, 2007, 8(3), 243-250. http://dx.doi.org/10.1007/ s10201-007-0212-6.

IZAGIRRE, O., AGIRRE, U., BERMEJO, M., POZO, J. and ELOSEGI, A. Environmental controls of whole-stream metabolism identified from continuous monitoring of Basque streams. Journal of the North American Benthological Society, 2008, 27(2), 252-268. http://dx.doi.org/10.1899/07-022.1.

KAUSHAL, S.S., DELANEY-NEWCOMB, K., FINDLAY, S.E.G., NEWCOMER, T.A., DUAN, S., PENNINO, M.J., SIVIRICHI, G.M., SIDESRALEY, A.M., WALBRIDGE, M.R. and BELT, K.T. Longitudinal patterns in carbon and nitrogen fluxes and stream metabolism along an urban watershed continuum. Biogeochemistry, 2014, 121(1), 23-44. http://dx.doi.org/10.1007/s10533-014-9979-9.

MALMQVIST, B. and RUNDLE, S. Threats to the running water ecosystems of the world. Environmental Conservation, 2002, 29(2), 134-153. http://dx.doi. org/10.1017/S0376892902000097.

MCDOWELL, W.H. Hurricanes, people, and riparian zones: controls on nutrient losses from forested Caribbean watersheds. Forest Ecology and Management, 2001, 154(3), 443-451. http://dx.doi. org/10.1016/S0378-1127(01)00514-X.
MCTAMMANY, M.E., BENFIELD, E.F. and WEBSTER, J.R. Recovery of stream ecosystem metabolism from historical agriculture. Journal of the North American Benthological Society, 2007, 26(3), 532-545. http://dx.doi.org/10.1899/06-092.1.

MEYBECK, M. Global analysis of river systems: from Earth system controls to Anthropocene syndromes. Philosophical Transactions of the Royal Society of London. Series B, Biological Sciences, 2003, 358(1440), 1935-1955. http://dx.doi.org/10.1098/ rstb.2003.1379. PMid:14728790.

MULHOLLAND, P.J., FELLOWS, C.S., TANK, J.L., GRIMM, N.B., WEBSTER, J.R., HAMILTON, S.K., MARTI, E., ASHKENAS, L., BOWDEN, W.B., DODDS, W.K., MCDOWELL, W.H., PAUL, M.J. and PETERSON, B.J. Inter-biome comparison of factors controlling stream metabolism. Freshwater Biology, 2001, 46(11), 1503-1517. http:// dx.doi.org/10.1046/j.1365-2427.2001.00773.x.

MULHOLLAND, P.J., HOUSER, J.N. and MALONEY, K.O. Stream diurnal dissolved oxygen profiles as indicators of in-stream metabolism and disturbance effects: Fort Benning as a case study. Ecological Indicators, 2005, 5(3), 243-252. http:// dx.doi.org/10.1016/j.ecolind.2005.03.004.

NAIDOO, R., BALMFORD, A., COSTANZA, R., FISHER, B., GREEN, R.E., LEHNER, B., MALCOLM, T.R. and RICKETTS, T.H. Global mapping of ecosystem services and conservation priorities. Proceedings of the National Academy of Sciences of the United States of America, 2008, 105(28), 9495-9500. http://dx.doi.org/10.1073/ pnas.0707823105. PMid:18621701.

NAZARENO, A.G. Brazil: combat the effects of forest code changes. Nature, 2012, 486(7402), 191. http:// dx.doi.org/10.1038/486191d.

NORTHINGTON, R.M., BENFIELD, E.F., SCHOENHOLTZ, S.H., TIMPANO, A.J., WEBSTER, J.R. and ZIPPER, C. An assessment of structural attributes and ecosystem function in restored Virginia coalfield streams. Hydrobiologia, 2011, 671(1), 51-63. http://dx.doi.org/10.1007/ s10750-011-0703-7.

O'DRISCOLL, C., O'CONNOR, M., ASAM, Z.U., DE EYTO, E., BROWN, L.E. and XIAO, L. Forest clearfelling effects on dissolved oxygen and metabolism in peatland streams. Journal of Environmental Management, 2016, 166, 250-259. http://dx.doi.org/10.1016/j.jenvman.2015.10.031. PMid:26513323.

PEARCE, N. and YATES, A. Agricultural best management practice abundance and location does not influence stream ecosystem function or water quality in the summer season. Water, 2015, 7(12), 6861-6876. http://dx.doi.org/10.3390/w7126661.

POSTEL, S. and CARPENTER, S. Freshwater ecosystem services. In G. DAILY, ed. Naturés services: 
societal dependence on natural ecosystems. Washington: Island Press, 1997, pp. 195-214.

RILEY, A.J. and DODDS, W.K. The expansion of woody riparian vegetation, and subsequent stream restoration, influences the metabolism of prairie streams. Freshwater Biology, 2012, 57(6), 1138-1150. http://dx.doi.org/10.1111/j.13652427.2012.02778.x.

ROLEY, S.S., TANK, J.L., GRIFFITHS, N.A., HALL, R.O. Jr. and DAVIS, R.T. The influence of floodplain restoration on whole-stream metabolism in an agricultural stream: insights fa 5-yrom ear continuous data set. Freshwater Science, 2014, 33(4), 1043-1059. http://dx.doi.org/10.1086/677767.

ROSA, R.S., AGUIAR, A.C.F., BOËCHAT, I.G. and GÜCKER, B. Impacts of fish farm pollution on ecosystem structure and function of tropical headwater streams. Environmental Pollution, 2013, 174, 204-213. http://dx.doi.org/10.1016/j. envpol.2012.11.034. PMid:23274449.

SANDIN, L. and SOLIMINI, A.G. Freshwater ecosystem structure-function relationships: from theory to application. Freshwater Biology, 2009, 54(10), 2017-2024. http://dx.doi.org/10.1111/ j.1365-2427.2009.02313.x.

SCHÄFER, R.B., BUNDSCHUH, M., ROUCH, D.A., SZÖCS, E., VON DER OHE, P.C., PETTIGROVE, V., SCHULZ, R., NUGEGODA, D. and KEFFORD, B.J. Effects of pesticide toxicity, salinity and other environmental variables on selected ecosystem functions in streams and the relevance for ecosystem services. The Science of the Total Environment, 2012, 415, 69-78. http://dx.doi.org/10.1016/j.scitotenv.2011.05.063. PMid:21802709.

SILVA, A., XU, Y.J., ICE, G., BEEBE, J. and STICH, R. Effects of timber harvesting with best management practices on ecosystem metabolism of a low gradient stream on the United States Gulf Coastal Plain. Water, 2013, 5(2), 747-766. http://dx.doi. org/10.3390/w5020747.

SILVA-JUNIOR, E.F. and MOULTON, T.P. Ecosystem functioning and community structure as indicators for assessing environmental impacts: Leaf processing and macroinvertebrates in Atlantic Forest streams. International Review of Hydrobiology, 2011, 96(6), 656-666. http://dx.doi.org/10.1002/ iroh.201111374.

SILVA-JUNIOR, E.F., MOULTON, T.P., BOËCHAT, I.G. and GÜCKER, B. Leaf decomposition and ecosystem metabolism as functional indicators of land use impacts on tropical streams. Ecological Indicators, 2014, 36, 195-204. http://dx.doi.org/10.1016/j. ecolind.2013.07.027.

SPONSELLER, R.A., BENFIELD, E.F. and VALETT, H.M. Relationships between land use, spatial scale and stream macroinvertebrate communities.
Freshwater Biology, 2001, 46(10), 1409-1424. http:// dx.doi.org/10.1046/j.1365-2427.2001.00758.x.

SUDDUTH, E.B., HASSETT, B.A., CADA, P. and BERNHARDT, E.S. Testing the field of dreams hypothesis: functional responses to urbanization and restoration in stream ecosystems. Ecological Applications, 2011, 21(6), 1972-1988. http://dx.doi. org/10.1890/10-0653.1. PMid:21939038.

SWEENEY, B.W., BOTT, T.L., JACKSON, J.K., KAPLAN, L.A., NEWBOLD, J.D., STANDLEY, L.J., HESSION, W.C. and HORWITZ, R.J. Riparian deforestation, stream narrowing, and loss of stream ecosystem services. Proceedings of the National Academy of Sciences of the United States of America, 2004, 101 (39), 14132-14137. http://dx.doi. org/10.1073/pnas.0405895101. PMid:15381768.

THORP, J.H. and DELONG, M.D. Dominance of autochthonous autotrophic carbon in food webs of heterotrophic rivers. Oikos, 2002, 96(3), 543-550. http://dx.doi.org/10.1034/j.16000706.2002.960315.x.

UEHLINGER, U. Annual cycle and inter-annual variability of gross primary production and ecosystem respiration in a floodprone river during a 15-year period. Freshwater Biology, 2006, 51(5), 938-950. http://dx.doi.org/10.1111/j.13652427.2006.01551.x.

VANNOTE, R.L., MINSHALL, G.W., CUMMINS, K.W., SEDELL, J.R. and CUSHING, C.E. The river continuum concept. Canadian Journal of Fisheries and Aquatic Sciences, 1980, 37(1), 130-137. http:// dx.doi.org/10.1139/f80-017.

VON SCHILLER, D., MARTÍ, E., RIERA, J.L., RIBOT, M., MARKS, J.C. and SABATER, F. Influence of land use on stream ecosystem function in a Mediterranean catchment. Freshwater Biology, 2008, 53(12), 2600-2612. http://dx.doi. org/10.1111/j.1365-2427.2008.02059.x.

VÖRÖSMARTY, C.J., MCINTYRE, P.B., GESSNER, M.O., DUDGEON, D., PRUSEVICH, A., GREEN, P., GLIDDEN, S., BUNN, S.E., SULLIVAN, C.A., LIERMANN, C.R. and DAVIES, P.M.Global threats to human water security and river biodiversity. Nature, 2010, 467(7315), 555-561. http://dx.doi.org/10.1038/nature09440. PMid:20882010.

WALLACE, J.B., EGGERT, S.L., MEYER, J.L. and WEBSTER, J.R. Effects of resource limitation on a detrital-based ecosystem. Ecological Monographs, 1999, 69(4), 409-442. http://dx.doi.org/10.1890/0012 9615(1999)069[0409:EORLOA]2.0.CO;2.

WEBSTER, J.R. and BENFIELD, E.F. Vascular plant breakdown in freshwater ecosystems. Annual Review of Ecology and Systematics, 1986, 17(1), 567-594. http://dx.doi.org/10.1146/annurev. es.17.110186.003031. 
YATES, A.G., BRUA, R.B., CULP, J.M. and CHAMBERS, P.A. Multi-scaled drivers of rural prairie stream metabolism along human activity gradients. Freshwater Biology, 2013, 58(4), 675-689. http://dx.doi.org/10.1111/fwb.12072.

YATES, A.G., BRUA, R.B., CULP, J.M., CHAMBERS, P.A. and WASSENAAR, L.I. Sensitivity of structural and functional indicators depends on type and resolution of anthropogenic activities. Ecological Indicators, 2014, 45, 274-284. http://dx.doi. org/10.1016/j.ecolind.2014.02.014.

YOUNG, R.G. and COLLIER, K.J. Contrasting responses to catchment modification among a range of functional and structural indicators of river ecosystem health. Freshwater Biology, 2009, 54(10), 2155-2170. http://dx.doi.org/10.1111/j.13652427.2009.02239.x.

YOUNG, R.G. and HURYN, A.D. Interannual variation in discharge controls ecosystem metabolism along a grassland river continuum. Canadian Journal of Fisheries and Aquatic Sciences, 1996, 53(10), 21992211. http://dx.doi.org/10.1139/f96-186.

YOUNG, R.G. and HURYN, A.D. Effects of land use on stream metabolism and organic matter turnover. Ecological Applications, 1999, 9(4), 1359-1376. http:// dx.doi.org/10.1890/1051-0761(1999)009[1359:EO LUOS]2.0.CO;2.

YOUNG, R.G., MATTHAEI, C.D. and TOWNSEND, C.R. Organic matter breakdown and ecosystem metabolism: functional indicators for assessing river ecosystem health. Journal of the North American Benthological Society, 2008, 27(3), 605-625. http:// dx.doi.org/10.1899/07-121.1.

Received: 05 February 2016

Accepted: 26 July 2016 